\title{
SYNTHESIS, CHARACTERIZATION, AND IN VITRO DEGRADATION OF POLY(LACTIC ACID) UNDER PETROLEUM PRODUCTION CONDITIONS
}

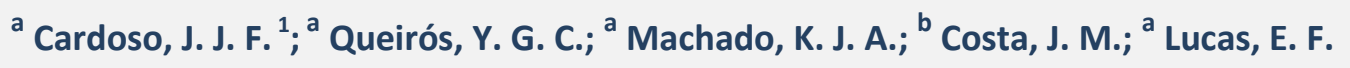

${ }^{\text {a }}$ Federal University of Rio de Janeiro, Institute of Macromolecules, Technological Center, Rio de Janeiro, RJ, Brazil

${ }^{b}$ Petrobras Research Center (CENPES), Ilha do Fundão, Q. 9, Rio de Janeiro, RJ, Brazil

\section{ABSTRACT}

Poly (d,I-lactic acid), PLA, was synthesized from lactic acid using two polymerization methods: direct polycondensation and ring opening polymerization. The effects of temperature, reaction time, and catalyst type were studied. Intrinsic viscosity determination, differential scanning calorimetry, and infrared spectrometry were used to characterize the polymers obtained. Gravimetric and colorimetry analyses were used to study polymer degradation under different environments varying $\mathrm{pH}$, temperature and salinity. The results showed that higher rates of degradation were obtained in higher $\mathrm{pH}$ and temperatures, and lower molar mass polymers presented a higher degradation rate. The outcome showed that it is possible to control the degradation rate under different petroleum production conditions. This makes the PLA a potential material to be used as a matrix for additives releasing systems.

\section{KEYWORDS}

poly (lactic acid); degradation; thermal analysis; petroleum production conditions

\footnotetext{
${ }^{1}$ To whom all correspondence should be addressed.

Address: Federal University of Rio de Janeiro, Institute of Macromolecules, Technological Center, BI. J, Ilha do Fundão, Rio de Janeiro, Brazil, P. O. Box 68525, Zip code 13083-860

Telephone / Fax: +5521 2562-8266/+5521 2270-1317| E-mail: jfcardoso@ima.ufri.br doi:10.5419/bjpg2013-0005
} 


\section{INTRODUCTION}

Degradable polymers have attracted great research interest due to its potential application in many areas. The degradation occurs mainly by cleavage of the main chain or the side chains of the macromolecules, which, in general, can be done by physical, chemical, mechanical, or biological agents (Albertsson and Karlsson, 1995). The environmental conditions, to which the polymer is exposed, such as $\mathrm{pH}$ and temperature, can influence degradation speed. Besides natural conditions, the polymer degradation process is also affected by the material's chemical and physical characteristics, such as molar mass, porosity, morphology, purity, chemical reactivity, and thermal and mechanical resistance (Alexis, 2005; Kumari et al., 2010).

The degradability has been studied for a number of natural and synthetic polymers, such as polysaccharides, polyanhydrides, polyols, polyurethanes, polyamides, acrylic polymers, and aliphatic polyesters (Severino et al., 2011). Poly (lactic acid), PLA, is a polymer of great interest, mainly due to its biodegradable characteristics. PLA is a polyester obtained from lactic acid (2hydroxypropionic acid). It can be synthesized at a wide range of molar masses through two different processes: (1) direct polycondensation of lactic acid and (2) ring opening polymerization (ROP) (Vert et al., 1995; Garlotta, 2001; Maharana, et al. 2009; Ajioka et al., 1998; Motta and Duek, 2006).

Due to its degradability, which can be induced solely by water or in conjunction with microorganisms (Auras et al. 2004; Li, 1999; Kumar et al., 2010), PLA has extensive applications, especially in biomedical (Jacobsen et al., 1999) and pharmaceuticals (Garlotta, 2001; Tokiwa and Jarerat, 2004). Many studies have addressed the degradation behavior of PLA induced by water (Li, 1999). Most of these studies have been carried out with the polymer totally submerged in a phosphate buffer saline solution, PBS, with a $7.4 \mathrm{pH}$, at $37^{\circ} \mathrm{C}$, to simulate the physiological environment (Albertsson and Karlsson, 1995; Nostrum et al., 1999; Yuan et al., 2002; Zhou et al., 2009; Pezzin et al., 2002).

Although the degradation of PLA occurs in a simple hydrolysis process, literature reports that the degradation depends on a wide range of factors that include molar mass, thermal treatment, crystallinity, purity, temperature, $\mathrm{pH}$, size, and shape of the sample (Auras et al., 2004; Ndazi and Karlsson, 2011). The degradation can also be influenced by the parameters of the environment to which it is exposed to. Due to the great potential of PLA, interest in its application has spread to other areas, such as agriculture (Zhao et al., 2005) and the petroleum industry (Drozd et al., 2004).

Numerous types of problems are common during all the steps of the oil extraction (Melo and Lucas, 2008; Ramalho et al., 2009; Garreto et al., 2010). These troubles increase as the depth of the reservoir increases, both beneath the surface and at the seafloor. Adverse conditions can affect severely the amount of oil brought to the surface, and, in extreme cases, can cause a producing well to become uneconomic before the reserves are fully tapped (Jacobs, 1988; Moreira et al., 1999; Vieira et al., 2008; Lima et al., 2010).

Solutions to the problems that affect the performance of producing wells can be obtained using chemical additives. These substances are among the best means to increase production, extend the well's useful life, and reduce the deterioration of the extraction equipment and flow lines (Machado and Lucas, 2002; Spinelli et al., 2006; Lucas et al., 2009; Cardoso et al., 2010). Additives action times vary according to the need of a particular application, from immediate use (to resolve imminent problems) or for prolonged use (to maintain specific conditions over the years) (Machado and Lucas, 2002; Fernandes et al., 2005).

Often, the simple injection of an additive, through a carrier fluid, is not the most efficient and cost-effective way to carry out the desired treatment (Gurgel et al., 2008; Amorim et al., 2011; Muniz et al. 2012). For this reason, researchers have been searching for novel manners of introducing chemical additives in oil wells (Oliveira et al., 2007).

The incorporation of a chemical additive by means of a protective polymer matrix is a new way of chemical treatment in oil fields. The polymer matrix, which traps a determined additive, tends to degrade under well conditions such as the type of aqueous medium, salinity, and $\mathrm{pH}$, releasing the additive in a controlled form to regulate the target 
problem (Erbstoesser, 1983).

In petroleum industry, the study of PLA polymers, considering its use as a degradable matrix for chemical additives, is still quite recent. Nevertheless, based on its characteristic of being degradable in aqueous medium, this polymer, along with the entire class of polyhydroxy acids to which it belongs, has excellent potential for application in this area. The degradation rate of these polymers can be modified according to the features of interest in releasing chemical additives. These additives are easy to mold and manipulate because of their thermoplastic characteristics (Tokiwa et al., 2004; Park, 1994).

This paper reports experiments to obtain PLA under different conditions. It also analyzes its degradation in different media. The experiments were performed under laboratory conditions, similar to those found in oil production.

\section{MATERIALS AND METHODS}

\subsection{Materials}

The major products used in this work were: $d, I-$ lactic acid, 85\% (Purac Sínteses Ind. e Com.); antimony trioxide (Carlo Erba do Brasil S.A.); stannous octoate (Agroquímica Maringá S.A.); ethyl acetate (Vetec Quimica Fina Ltda); and $p$ hydroxydiphenyl (Sigma Aldrich S.A.).

\subsection{Preparation of poly (lactic acid)}

The poly (lactic acid) acid was produced by direct polycondesation and open ring polymerization. In both cases, the systems were heated at $130^{\circ} \mathrm{C}$, under atmospheric pressure, to remove water. For direct polycondensation, antimony trioxide $(0.1 \% \mathrm{wt} / \mathrm{wt})$ was used as catalyst. The total reaction time was five hours. During the reaction, three polymer aliquots were removed at the end of the first, fourth, and fifth hour, respectively. The temperature was increased from $150^{\circ} \mathrm{C}$ to $210^{\circ} \mathrm{C}$ and, then, to $230^{\circ} \mathrm{C}$, after taking the first and the second aliquot (Table 1 ). The reaction was carried out at reduced pressure (10-20 $\mathrm{mmHg}$ ) (Garlotta, 2001). Using the opening ring polymerization, the lactide ring was formed after removing the water. Then, the polymerization took place at $160^{\circ} \mathrm{C}$, and $10-20 \mathrm{mmHg}$ of pressure using stannous octoate $(0.1 \%)$ as catalyst. Two aliquots were taken, one at the end of the first hour and the second at the end of the sixth hour (Garlotta, 2001).

\subsection{Characterization of poly (lactic acid)}

The molar masses were determined by viscometry using an Ubbelohde $\mathrm{OB}$ viscosimeter placed in a water-bath thermostatically controlled at $23^{\circ} \mathrm{C}$. The polymers were dissolved in chloroform, at concentrations ranging from $5-10 \%$ $(w t / v)$. The intrinsic viscosity [ $\eta$ ] of each polymer was obtained by extrapolating it to zero concentration. From these results, the molar mass (M) was calculated using the Mark-HouwinkSakurada equation (Brandrup and Immergut, 1989), using $\mathrm{k}=2.46 \times 10^{-7}$, and $\mathrm{a}=1.49$ (Deasy et al., 1989).

$[\eta]=k \cdot M^{a}$

Fourier transform infrared spectroscopy (FTIR) was used to obtain the spectra of the lactic acid and PLA samples, which were analyzed as films, after casting and evaporating polymer solution in chloroform (1\%) on an $\mathrm{NaCl}$ pellet. A Perkin-Elmer 1720 FTIR spectrometer, at a range of 4000 to $400 \mathrm{~cm}^{-1}$ and with a scan of $2 \mathrm{~cm}^{-1}$, was used.

The heat flow curves as a function of temperature were obtained in a Perkin-Elmer, DSC7 differential scanning calorimeter under nitrogen flow of $20 \mathrm{~mL} / \mathrm{min}$, at temperatures ranging from 35 to $100^{\circ} \mathrm{C}$, at a heating rate of $20^{\circ} \mathrm{C} / \mathrm{min}$.

Thermogravimetric analyses were carried out in a Perkin-Elmer TGA-7, under nitrogen flow of $35 \mathrm{~mL} / \mathrm{min}$, from 30 to $450^{\circ} \mathrm{C}$, at a heating rate of $20^{\circ} \mathrm{C} / \mathrm{min}$.

\subsection{Degradation studies}

The five different polymers samples prepared were submitted to four distinct contact conditions: (1) distilled water; (2) seawater; (3) a buffer solution with $\mathrm{pH}$ of 9.6; and (4) a buffer solution with $\mathrm{pH}$ of 3.0. Triplicate results were obtained. Samples of $0.2 \mathrm{~g}$ of polymer in $40 \mathrm{~mL}$ of each solvent were placed in recipients and submitted to temperatures ranging from 23 and $70^{\circ} \mathrm{C}$. The materials were removed for analysis using gravimetric and colorimetric methods in time spans of 15 days for a total period of 60 days. 
The polymers added to the different media were filtered after the predetermined degradation time. Then the filtered mass was placed in a vacuum chamber at $40^{\circ} \mathrm{C}$ for 48 hours, after which the residue was weighed. The degradation mass was calculated by Equation 2 .

$\%$ mass loss $=\left(m_{i}-m_{d}\right) / m_{i} \times 100$

where $m_{i}$ is the polymer's initial mass and $m_{d}$ is the remaining dry mass of the polymer after degradation.

The samples were also analyzed through the colorimetric method (UV-Vis Celme E205-D), by plotting a response curve using the following method: various monomer solutions in distilled water, with concentrations ranging from 0.1 to $5.0 \mu \mathrm{g} / \mathrm{mL}$, were treated with a solution of $4 \%$ copper sulfate and concentrated sulfuric acid. Then, the solutions were heated in boiling water for five minutes and cooled immediately to room temperature. After the addition of $p$ hydroxydiphenyl, the system was heated again until boiling, and kept under the same conditions for 90 seconds. Following, the samples were analyzed at $620 \mathrm{~nm}$ (Chu and Louie, 1985). The samples submitted to degradation were analyzed using the same procedures, and their monomer contents were determined using the response curve.

\section{RESULTS AND DISCUSSIONS}

\subsection{Polymer characterization}

Table 1 shows the reaction conditions to obtain poly (lactic acid), the label used to identify the samples, and the molar mass results. Although the

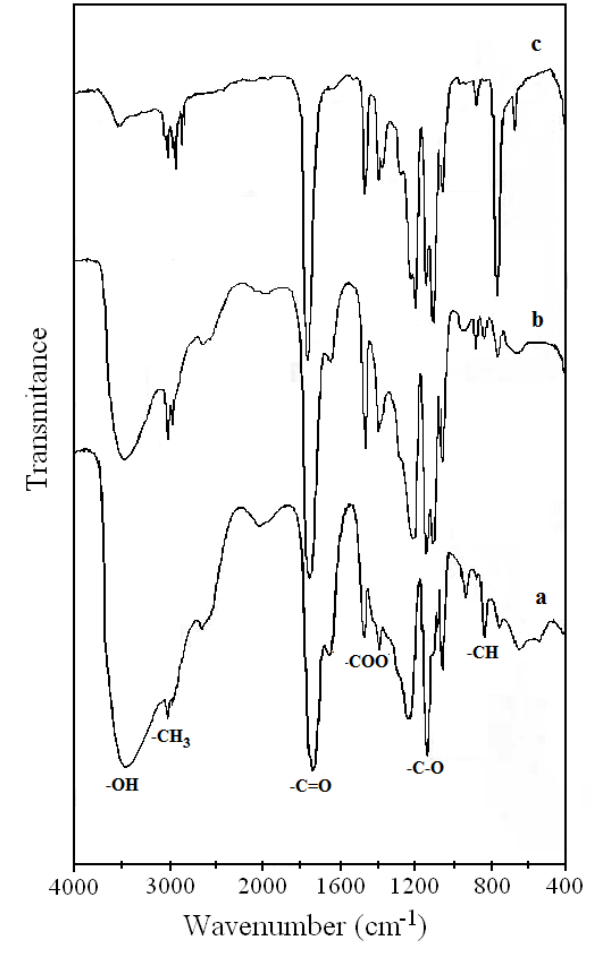

Figure 1. Infrared spectra of the samples: (a) Monomer, (b) PLA 1-1 and (c) PLA 1-3.

polymers have been synthesized by two different routes to obtain different molar masses, similar values were obtained by comparing the two techniques, most likely due to the high viscosity after removing the water step. Five samples with different molar masses were obtained. These samples were deemed suitable for use in the study of degradation under oil production conditions, considering that the experiment was not seeking a very long degradation time.

The FTIR spectra of the monomer and the polymer samples PLA 1-1 and PLA 1-3 are shown in Figure 1 . The spectra of all the polymer samples

Table 1. Synthesis conditions and molar masses of poly (lactic acid).

\begin{tabular}{|c|c|c|c|c|c|}
\hline $\begin{array}{l}\text { Polymer } \\
\text { sample }\end{array}$ & $\begin{array}{c}\text { Polymerization } \\
\text { type }\end{array}$ & Catalyst & $\begin{array}{c}\text { Reaction } \\
\text { temperature }\left({ }^{\circ} \mathrm{C}\right)\end{array}$ & $\begin{array}{l}\text { Reaction time } \\
\text { (h) }\end{array}$ & $\begin{array}{c}\langle\mathrm{Mv}\rangle \\
\left(\mathrm{g} \cdot \mathrm{mol}^{-1}\right)\end{array}$ \\
\hline PLA 1-1 & \multirow{3}{*}{ Direct polycondensation } & \multirow{3}{*}{$\begin{array}{l}\text { Antimony } \\
\text { trioxide }\end{array}$} & 150 & 1 & 1,770 \\
\hline PLA 1-2 & & & 210 & 4 & 5,080 \\
\hline PLA 1-3 & & & 230 & 5 & 5,680 \\
\hline PLA 2-1 & \multirow{2}{*}{$\begin{array}{l}\text { Ring opening } \\
\text { polymerization }\end{array}$} & \multirow{2}{*}{$\begin{array}{l}\text { Stanous } \\
\text { octoate }\end{array}$} & \multirow{2}{*}{160} & 1 & 4,750 \\
\hline PLA 2-2 & & & & 6 & 6,750 \\
\hline
\end{tabular}


Table 2. Degradation temperatures of the PLA samples.

\begin{tabular}{ccc}
\hline Polymer sample & $\begin{array}{c}\text { Start of degradation } \\
\text { temperature }\left({ }^{\circ} \mathrm{C}\right)\end{array}$ & $\begin{array}{c}\text { Onset temperature } \\
\left({ }^{\circ} \mathrm{C}\right)\end{array}$ \\
PLA 1-1 & 45 & 202 \\
PLA 1-2 & 120 & 260 \\
PLA 1-3 & 140 & 307 \\
PLA 2-1 & 100 & 295 \\
PLA 2-2 & 145 & 280 \\
\hline
\end{tabular}

show absorption peaks, characteristic of ester bonds (1750 to $\left.1735 \mathrm{~cm}^{-1}\right), \mathrm{CH}_{3}$ groups $\left(2945 \mathrm{~cm}^{-1}\right)$, and $\mathrm{OH}$ groups $\left(3508 \mathrm{~cm}^{-1}\right.$ ) (Motta and Duek, 2006; Chu and Louie, 1985). The peak, characteristic of the $\mathrm{OH}$ groups $\left(3500 \mathrm{~cm}^{-1}\right)$, which is significant in the monomer's spectrum, practically disappeared in the spectra of the polymers synthesized with longer reaction time. This outcome confirms the increase of conversion with time. An exception was observed in the spectrum of sample PLA 1-1, which had a broad band characteristic of the $\mathrm{OH}$ group. This diverse result can be explained by the fact that the aliquot of this material was obtained with shorter reaction time and, consequently, contained a relatively higher quantity of still unreacted hydroxyls. The lower conversion of PLA 1-1 was also confirmed by the short peak, related to $-\mathrm{CH}$, at $820 \mathrm{~cm}^{-1}$. After opening the ring to form the polymer chain, more $-\mathrm{CH}$ groups were formed, increasing the intensity of this band. The band at $1150 \mathrm{~cm}^{-1}$, related to $-\mathrm{CO}$, is broader in polymers than in monomers due to the overlapping of monomer and polymer contribution, since the polymer sample may contain some unreacted

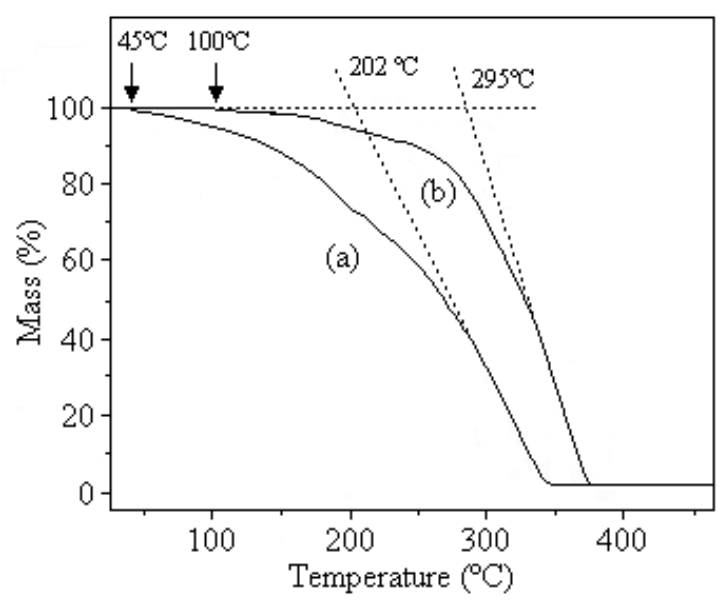

Figure 2. Mass-loss curves in function of temperature for (a) PLA 1-1, and (b) PLA 2-1. monomer.

Thermal analysis is a good tool to study polymer behavior in terms of transitions and degradation (Brostow, 2000; Lucas et al., 2001). The differential scanning calorimetry (DSC) curves obtained for the PLA 1-2, PLA 1-3 and PLA 2-2 only presented a discontinuity of the baseline related to the glass transition event. As expected, no peaks related to the crystalline phase melting temperature were observed. This result is in line with the fact that polymerization of racemic monomer ( $D, L$ lactic acid) mixtures result in amorphous polymers, essentially. Thermal, mechanical, and biodegradable properties along with the degree of PLA crystallinity depend strongly on the ratio and distribution of the two stereoisomers in the polymer chain (Maharana et al., 2009). The glass transition temperature (Tg) of the PLA 1-2, PLA 1-3 and PLA 2-2 samples were, respectively, 58, 58 and $39^{\circ} \mathrm{C}$, even though these samples have very close molar mass values (Table 1). For the polymers obtained by direct polycondensation, the difference in molar mass from 5,080 to 5,680 was not sufficient to alter the Tg. However, the sample with molar mass of 6,750 , obtained by ring opening polymerization, had a significantly lower $\mathrm{Tg}$ value. This result suggests that the product obtained in two steps (ring opening polymerization) contains unreacted lactide, which is responsible for reducing the $\mathrm{Tg}$ value.

Table 2 presents the onset temperatures (elongation of the segments) and start of mass loss of the polymers. As expected, the thermal stability increased with higher molar masses. The profiles of the thermal degradation curves were very similar for each of the families of samples obtained (PLA 1 and PLA 2). Figures $2 a$ and $2 b$ present the mass-loss curves in function of temperature for PLA 1-2 and PLA 2-1, respectively. The figures show the onset and start of degradation temperatures. The PLA 1 family shows mass loss in two well-defined stages, 


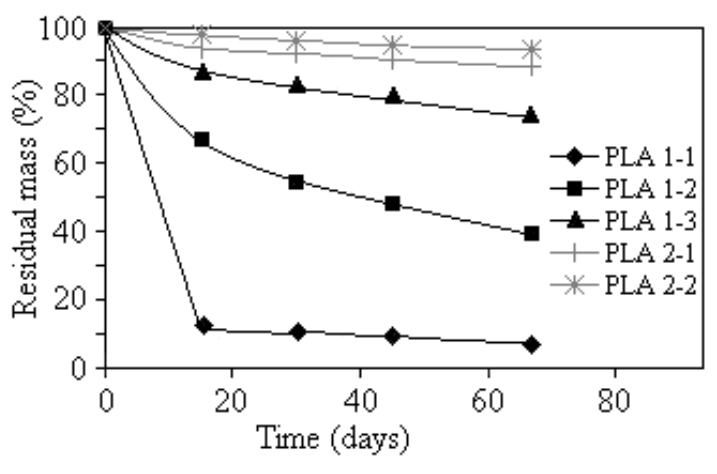

Figure 3. Gravimetric analysis of PLA in water with

$\mathrm{pH} 6.5$ at $23^{\circ} \mathrm{C}$.

while the PLA 2 family's first stage only appears in the form of a shoulder for the main degradation stage. Other researchers have reported thermal degradation of PLA in only one stage (Zou et al., 2009; Nalbandi, 2001; Kopinke et al., 1996). However, the results of this study can be related to the low molar masses of the polymers, the wide molar mass distribution, and, in the case of the samples obtained by ring opening, to the presence of lactide in the sample.

\subsection{Degradation studies}

The in vitro degradation of poly(lactic acid) was studied for a possible application in the production of polymeric microspheres to promote the encapsulation of chemical additives in controlled release systems in the petroleum industry. The study of the polymer's degradation profile was carried out in function of the influence of its molar mass and the medium's $\mathrm{pH}$ and temperature conditions. The PLA samples were added to four media, distilled water, seawater, a solution with $\mathrm{pH}$ of 3.0, and a solution with pH of 9.6, to ascertain whether or not these media influence on the degradation process.

\subsubsection{Influence of the molar mass and type of polymerization}

The degradation of PLA occurs by the cleavage of the ester bonds in the polymer chains. Since the water hydrolyzes the chains randomly, the polymer molar mass is reduced and soluble oligomers are produced. Therefore, the polymer's degradation can be accompanied by monitoring the mass loss after a determined time interval (Saha and Tsuji, 2006).

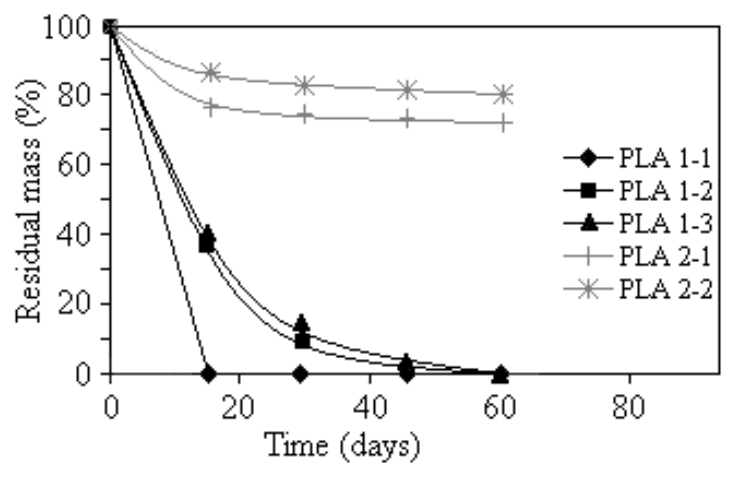

Figure 4. Gravimetric analysis of PLA in $\mathrm{pH} 9.6$ at

$23^{\circ} \mathrm{C}$.

Figure 3 shows the percentage of residual mass as a function of time for all PLA samples in water at $23^{\circ} \mathrm{C}$. The observation of Figure 3 allows one to conclude that the higher the molar mass samples exhibit, the higher the stability is. PLA 1-1 lost mass much more quickly than the others, even under the least severe conditions ( 15 days, at $23^{\circ} \mathrm{C}$. Hence, this polymer may be suitable for applications where it is necessary to release a sort of additive encapsulated in its matrix rapidly.

Figure 4 shows the influence of polymerization type on the degradation. The plot shows that the polymers obtained by ring opening polymerization are more resistant to degradation than those obtained by direct polycondensation. This behavior can be observed for all the degradation media to which these polymers were exposed to. The greater resistance to degradation shown by the PLA 2 family can be observed in Figure 4, where polymers produced by direct polycondensation (PLA 1) showed total degradation at the end of 60 days of exposure. In contrast, those obtained by ring opening (PLA 2) did not degrade more than $20 \%$, even after the same 60 days of exposure. This suggests there is another factor, besides molar mass, which is able to restrain the hydrolytic cleavage.

A comparison between PLA 1-3 and PLA 2-1 samples can be done using the data from Figure 4 . The plot shows that the samples have relatively close molar masses, and demonstrate the influence of the method that obtain polymer on its degradation behavior. The PLA 1-3 sample obtained by direct polycondensation had a slightly higher degradation speed, despite presenting a higher molar mass than PLA 2-1 sample obtained 
Table 3. Comparison from the degradation between two polymers under alkaline environment $\left(\mathrm{pH} 9.6\right.$ at $\left.23^{\circ} \mathrm{C}\right)$

\begin{tabular}{ccccccc}
\hline \multirow{2}{*}{ Polymers } & \multirow{2}{*}{} & $<$ Mv $>$ & \multicolumn{5}{c}{ Residual mass (\%) } \\
\cline { 3 - 7 } & & 0 day & $\mathbf{1 5}$ days & 30 days & $\mathbf{4 5}$ days & $\mathbf{6 0}$ days \\
\hline PLA 1-3 & 5,680 & 100.0 & 40.9 & 13.7 & 2.1 & 0.0 \\
PLA 2-1 & 4,750 & 100.0 & 77.3 & 75.1 & 73.4 & 72.1 \\
\hline
\end{tabular}

by ring opening. This behavior was more accentuated in a more aggressive degrading medium with $\mathrm{pH} 9.6$, at $23^{\circ} \mathrm{C}$, shown in Table 3 . Under these conditions, the greater resistance of the PLA 2-1 sample in relation to PLA 1-3 is evident. After 15 days, PLA 2-1 had a residual mass that was nearly twice as large as PLA 1-3 (40.9\%).

The differences between the sample's residual masses can be explained using the following argument: although the poly (d,I-lactic acid) is predominantly amorphous, it contains a small crystalline portion, which can influence its behavior. Annealing may occur during its synthesis by ring opening, which occurs at $160^{\circ} \mathrm{C}$, since the temperature is maintained, for a long period, between the glass transition temperature $(\mathrm{Tg}=49$ $52^{\circ} \mathrm{C}$ ) and the crystalline phase melting temperature of commercially available PLA, 185으 (Brandrup and Immergut, 1989). The annealing is responsible for the better formation of the crystalline domains, which, even in small quantities, can promote the increased resistance to degradation observed in this sample.

The results presented, up to this point, indicate that the choice of using the polymer as a matrix

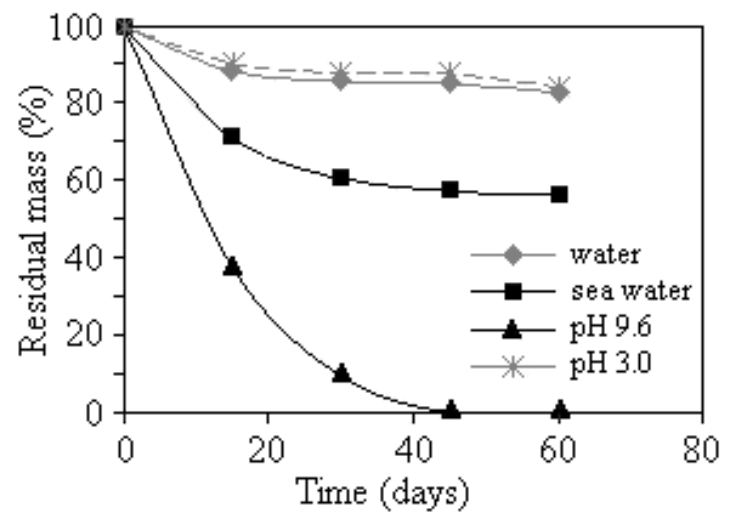

Figure 5. Gravimetric analysis of PLA $1-2$ at $23^{\circ} \mathrm{C}$. must be made carefully, in order to obtain the desired behavior of the material in relation to the type of application required. For example, in subsea environments, at ambient temperature, these polymers can be used as matrixes for biocides. In that capacity, these chemical substances are stored in tanks to release the additive for a long period of time. Biocides can be used at high temperatures in petroleum production, also functioning as an additive matrix for various oilfield applications, where the additive's release can be customized by choosing the type of polymer in function of the medium to which it will be exposed to.

\subsubsection{Influence of $\mathrm{pH}$}

The systems were exposed to two extreme $\mathrm{pH}$ values: a strongly acidic one ( $\mathrm{pH} 3.0)$ and a strongly alkaline one (pH 9.6). Distilled water was chosen as the degradation agent because its $\mathrm{pH}$ value of 6.5 is close to neutral, allowing the results of the experiments to serve as reference parameter. The majority of the degradation studies have been carried out in a phosphate buffer saline solution with $\mathrm{pH}$ 7.4, simulating the physiological environment (Albertsson and Karlsson, 1995; Nostrum et al., 2004; Zhou et al., 2009). Finally, because the aim of this work was to study the use of this polymer in offshore oil production and storage, the influence of seawater $(\mathrm{pH} 8.2)$ as a degrading medium was also studied. All the systems were studied at both 23 and $70^{\circ} \mathrm{C}$.

Figure 5 shows the behavior of the PLA 1-2 sample exposed to the different media at $23^{\circ} \mathrm{C}$. A comparison of the degradation media shows clearly that as the $\mathrm{pH}$ rises, so does the polymer's degradation rate. For the $\mathrm{pH} 3$ and $\mathrm{pH} 6.5$ media (distilled water), the degradation rates are very similar. This pattern of behavior was observed for all the samples. In a more alkaline medium $(\mathrm{pH}$ 9.6), the polymer samples were totally degraded and also presented high degradation speeds, 
Table 4. Results of PLA degradation on seawater.

\begin{tabular}{ccccccc}
\hline & \multicolumn{5}{c}{ Residual mass (\%) } \\
\cline { 2 - 7 } Polymer & \multicolumn{2}{c}{$\mathbf{1 5}$ days } & \multicolumn{2}{c}{$\mathbf{4 5}$ days } & \multicolumn{2}{c}{$\mathbf{6 0}$ days } \\
\cline { 2 - 7 } & $\mathbf{2 3 ^ { \circ } \mathbf { C }}$ & $\mathbf{7 0 ^ { \circ } \mathbf { C }}$ & $\mathbf{2 3}^{\circ} \mathbf{C}$ & $\mathbf{7 0 ^ { \circ } \mathbf { C }}$ & $\mathbf{2 3}^{\circ} \mathbf{C}$ & $\mathbf{7 0}^{\circ} \mathbf{C}$ \\
\hline PLA 1-1 & 9.1 & 1.5 & 8.8 & 0.0 & 8.8 & 0.0 \\
PLA 1-2 & 72.8 & 40.2 & 60.7 & 15.0 & 56.1 & 0.0 \\
PLA 1-3 & 82.7 & 49.8 & 68.7 & 16.5 & 66.8 & 0.0 \\
PLA 2-1 & 82.7 & 48.9 & 78.9 & 17.8 & 66.8 & 0.0 \\
PLA 2-2 & 88.5 & 54.2 & 84.2 & 19.6 & 82.1 & 0.0 \\
\hline
\end{tabular}

producing clear solutions in many cases after 15 to 30 days. The presence of $\mathrm{OH}$ ions in the alkaline medium catalyzes the hydrolysis of the ester bonds faster than in the acid medium, which accelerates the polymers' degradation process (Cam et al., 1995; Barbanti et al., 2006).

Based on previous knowledge, one expected that seawater $(\mathrm{pH}$ 8.2) would induce a higher degradation rate, near that observed for the $\mathrm{pH} 9.6$ medium, due to the similarity of these $\mathrm{pH}$ values. However, although the degradation rate increased as the $\mathrm{pH}$ did, this relation was not linear. The media with $\mathrm{pH} 3$ and $\mathrm{pH} 6.5$ caused relatively close degradation rates, while the difference in residual mass after 60 days for the $\mathrm{pH} 8.2$ and 9.6 media in some cases reached $60 \%$. The literature mentions that the presence of salts in the medium accelerates the degradation of polymers (Makino et al., 1985). In this study, the influence of the salts present in the seawater was not enough to overcome the difference in degradation rate

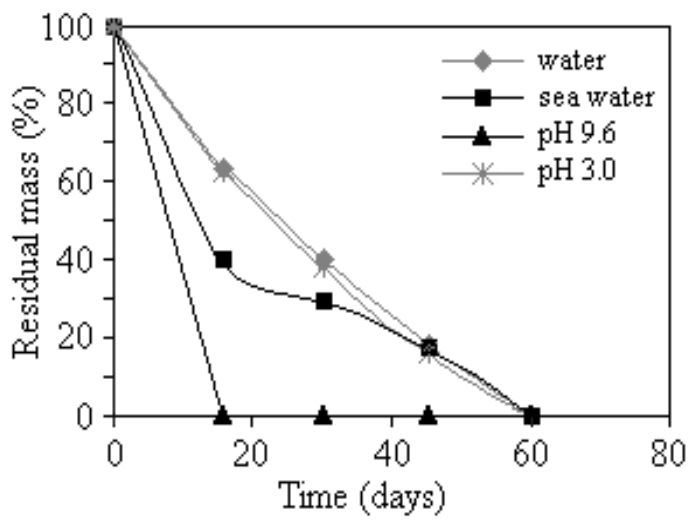

Figure 6. Gravimetric analysis of PLA $1-2$ at $70^{\circ} \mathrm{C}$. induced under the extreme $\mathrm{pH} 9.6$ condition.

The acidic medium was not highly aggressive to this polymer - the degradation rate was relatively low, meaning that the acidic degradation appears to be less efficient. This behavior presents a big advantage for use in production fields. In those fields, the matrix containing a certain type of additive would not undergo an accentuated variation in the pre-programmed speed at which the reservoir would be exposed to intervention with acidic fluids.

\subsubsection{Influence of temperature}

A comparison between Figure 5 and Figure 6 clearly denotes the accentuated effect of temperature on the degradation rate of the samples of PLA 1-2. At $70^{\circ} \mathrm{C}$, the samples show the same behavior pattern, that is, increased degradation rate as $\mathrm{pH}$ rises, in nonlinear form.

However, for each $\mathrm{pH}$ condition, the degradation rates were much higher when the samples were submitted to a temperature of $70^{\circ} \mathrm{C}$. In this case, under all $\mathrm{pH}$ conditions, there was no residual mass after 60 days. This is significant because in most media, after 15 days, at $70^{\circ} \mathrm{C}$, the degradation was greater than after the full 60 days at $23^{\circ} \mathrm{C}$. Table 4 shows the residual mass values for all the polymers exposed to seawater, at both temperatures $\left(23\right.$ and $\left.70^{\circ} \mathrm{C}\right)$. The degradation of all the polymers at $70^{\circ} \mathrm{C}$ was much greater than at $23^{\circ} \mathrm{C}$.

The difference in degradation speed as a function of temperature is shown clearly in Figure 7, where the percentage curves of the residual mass as a function of time are plotted for the PLA 


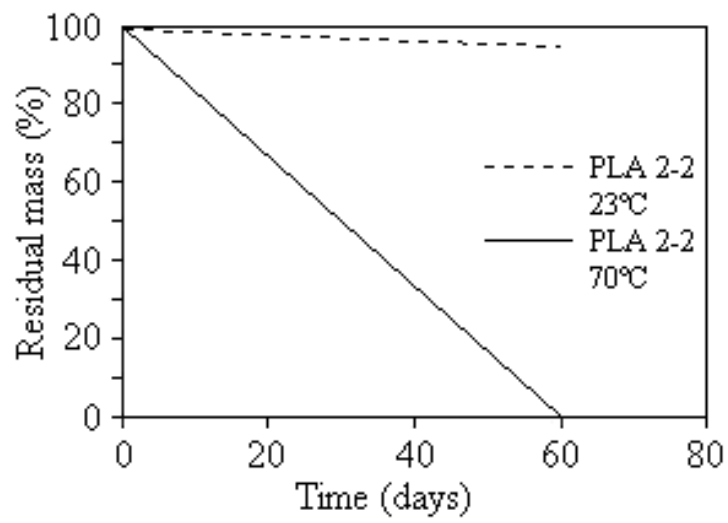

Figure 7. Degradation comparison of PLA 2-2 in seawater.

2-2, in seawater at the two temperatures. The results for seawater, plotted in Figure 7, were used because the degradation of the polymers in this medium was nearly linear. The angular coefficients, estimated visually by the slopes of the curves at $70^{\circ} \mathrm{C}$, are considerably greater than those at $23^{\circ} \mathrm{C}$. Although one can predict an increase in the degradation rate with the increase in temperature, the effect observed at $70^{\circ} \mathrm{C}$ was much more accentuated. Probably, in this case, the system is undergoing the influence of two factors: the temperature itself and the fact the PLA was above its glass transition temperature $\left(\mathrm{Tg}=49-52^{\circ} \mathrm{C}\right)$ (Brandrup and Immergut, 1989). Glass transition takes place over a temperature region, not at a single temperature (Kalogeras and Lobland, 2012). The monomer used in this study ( $d, I$ lactic acid) generated amorphous polymers predominantly. A polymer exposed to a temperature above its $\mathrm{Tg}$ presents great mobility of this amorphous phase. This mobility facilitates the diffusion of the degradation agents in the polymer matrix (Schhnabel, 1981), consequently favoring the degradation process. Above the glass transition, if the polymer is semi-crystalline, there is a presence of liquid and crystals (Orozco et al., 2009). The correlation between the mobility of the polymer chain and the speed of its degradation is discussed in the literature (Tracy and Ward, 1999) in terms of the crystallinity degree. The degradation rate in these polymers is inversely proportional to their crystallinity. Samples of semi-crystalline and crystalline PLA can be obtained, respectively, from polymerization of the monomers I-lactic acid and dlactic acid. Consequently, one can obtain materials that degrade more slowly and, thus, are more resistant to high temperatures.

\subsection{Comparison between the methods of analysis}

Gravimetry is a technique used widely because it is cheap and very precise in analyzing degradation. As such, it is used often to study PLA. However, it is a very laborious technique, which demands care over a long period of time to furnish the desired results. Therefore, as an alternative, this work used an alternative technique of colorimetry to analyze the monomers produced during the degradation period. The comparative results, presented in Table 5, show that the differences between the polymer degradation percentages obtained by the two methods do not exceed $2 \%$. The agreement of the results obtained by these two techniques proves their precision. Colorimetry offers the advantage of speed, since it allows one to work on large number of samples at the same time, and simplicity. On the other hand, the benefit of the gravimetric method lies on the fact that it does not require the use of any specific equipment or reagents.

Table 5. Percentage of polymer degraded, in seawater, determined by gravimetry and colorimetry.

\begin{tabular}{|c|c|c|c|c|c|}
\hline \multirow{3}{*}{\multicolumn{2}{|c|}{ Polymer }} & \multicolumn{4}{|c|}{ Polymer degradation performance (\%) } \\
\hline & & \multicolumn{2}{|c|}{ Gravimetry method } & \multicolumn{2}{|c|}{ Colorimetry method } \\
\hline & & 15 days & 45 days & 15 days & 45 days \\
\hline PLA 1-1 & \multirow{3}{*}{$23^{\circ} \mathrm{C}$} & 90.9 & 91.2 & 91.6 & 96.0 \\
\hline PLA 1-3 & & 17.3 & 31.3 & 16.0 & 26.6 \\
\hline PLA 2-2 & & 11.5 & 15.8 & 12.8 & 15.8 \\
\hline PLA 1-1 & \multirow{3}{*}{$70^{\circ} \mathrm{C}$} & 98.5 & 100.0 & 98.8 & 100.0 \\
\hline PLA 1-3 & & 50.2 & 83.9 & 51.2 & 83.8 \\
\hline PLA 2-2 & & 45.8 & 80.4 & 46.0 & 79.2 \\
\hline
\end{tabular}




\section{CONCLUSIONS}

The degradation of poly (lactic acid), PLA, occurs more quickly in fractions of polymers with lower molar masses. However, the medium to which the samples were submitted to has a predominant influence on their degradation rate. Greater degradation rates were observed in a more alkaline medium $(\mathrm{pH}$ 9.6) and at a higher temperature $\left(70^{\circ} \mathrm{C}\right)$. The degradation rate did not increase linearly with an increase in $\mathrm{pH}$ value. Such rate was much more accentuated for more alkaline $\mathrm{pH}$ values. The induction of degradation at $70^{\circ} \mathrm{C}$ appeared to be associated with the mobility of the polymer chain, which was above its $\mathrm{Tg}\left(49-51^{\circ} \mathrm{C}\right)$.

The degradation of PLA takes into account various parameters, to include $\mathrm{pH}$, temperature, monomer concentration in the medium, molar mass, and polymer chain arrangements. The degradation is induced by a synergy of these factors in conjunction with other features associated with the degradation system.

The wide range of substances produced by the same type of polymer showed the great flexibility of PLA to degradation. The polymer can be degraded totally in only a few days, or maintained almost unaffected for more than two months. The PLA can be an excellent matrix to deliver chemical additives in the oil industry, since its degradation can be controlled. The acceleration or retardation of the degradation process can be monitored by adding an agent in the carrier fluid. This control may also occur by selecting the most suitable polymer from knowledge of the medium that will be used.

\section{ACKNOWLEDGMENTS}

Funding for this study was supplied by the research agencies CNPq, ANP/FINEP/CTPETRO and CENPES/Petrobras.

\section{REFERENCES}

Ajioka, M.; Suizu, H.; Higuchi, C.; Kashima, T. Aliphatic polyesters and their copolymers synthesized through direct condensation polymerization. Polymer Degradation and Stability, v. 59, p. 137-143, 1998. http://dx.doi.org/10.1016/S0141-3910(97)00165-1
Albertsson, A. C.; Karlsson, S. Degradable polymers for the future. Acta Polymerica, v. 46, p. 114-123, 1995.

http://dx.doi.org/10.1002/actp.1995.010460203

Alexis, F. Factors affecting the degradation and drug-release mechanism of poly(lactic acid) and poly[(lactic acid)-co-(glycolic acid)]. Polymer International, v. 54, p. 36-46, 2005.

http://dx.doi.org/10.1002/pi.1697

Amorim, L. V.; Nascimento, R. C. A. M.; Lira, D. S.; Magalhães, J. Evaluation of The Behavior of Biodegradable Lubricants in The Differential Sticking Coefficients of Water based Drilling Fluids. Brazilian Journal of Petroleum and Gas, v. 5(4), p. 197-207, 2011. http://dx.doi.org/10.5419/bjpg2011$\underline{0019}$

Auras, R.; Harte, B.; Selke, S. An Overview of Polylactides as Packaging Materials. Macromolecular Bioscience, v. 4, p. 835-864, 2004. http://dx.doi.org/10.1002/mabi.200400043

Barbanti, S. H.; Zavaglia, C. A. C.; Duek, E. A. R. Degradação Acelerada de Suportes de Poli( $\varepsilon$ Caprolactona) e Poli(D,L-Ácido Láctico-co-Ácido Glicólico) em Meio Alcalino. Polímeros: Ciência e Tecnologia, v. 16, p. 141-148, 2006. http://dx.doi.org/10.1590/S0104-14282006000200015

Brandrup, V.; Immergut, E.H. Polymer Handbook. New York: John Wiley \& Sons, 1989.

Brostow, W. Performance of Plastics. Cincinnati: Hanser/Gardner Publications, Inc., 2000.

Cam, D.; Hyon, S-H.; Ikada, Y. Degradation of high molecular weight poly(L-lactide) in alkaline medium. Biomoterials, v. 16, p. 833-843, 1995. http://dx.doi.org/10.1016/0142-9612(95)94144-A

Cardoso, J. J. F.; Spinelli, L. S.; Monteiro, V.; Lomba, R.; Lucas, E. F. Influence of polymer and surfactant on the aphrons characteristics: Evaluation of fluid invasion controlling. eXPRESS Polymer Letters, v. 4, p. 474-479, 2010.

Chu, C.; Louie, M. A chemical means to study the in vitro hydrolytic degradation of poly(glycolic acid). Journal of Applied Polymer Science, v. 30, p. 3133-3141, 1985.

http://dx.doi.org/10.1002/app.1985.070300802 
Deasy, P. B.; Finan, M. P.; Meegan, M. J. Preparation and Characterization of Lactic/Glycolic Acid Polymers and Copolymers. Journal of Microencapsulation, v. 6, p. 369-378, 1989. http://dx.doi.org/10.3109/02652048909019919

Drozd, J. C.; Martin, H.R.; Blakemore, T. J.; Kelly, D.; Hudgens, $D$. Controlled release additives in fuel systems, 6827750, USA,2004.

Erbstoesser, S. R.; Cooke, C. E.; Sinclair, R.G.; Epstein, M.M. Composition for reducing permeability of subterranean formations, 4.526.695, USA, 1983.

Fernandes, R.S.; González, G.; Lucas, E. F. Assessment of polymeric flocculants in oily water systems. Colloid and Polymer Science, v. 283, 375382, 2005. http://dx.doi.org/10.1007/s00396-004$\underline{1153-9}$

Garlotta, D. A Literature Review of Poly(Lactic Acid). Journal of Polymers and the Environment, v. 9, p. 63-84, 2001.

http://dx.doi.org/10.1023/A:1020200822435

Garreto, M. S. E.; Gonzalez, G.; Ramos, A. C.; Lucas, E. F. Looking for a model solvent to disperse asphaltenes. Chemistry \& Chemical Technology, v.4, p.317-323, 2010.

Gurgel, A.; Moura, M. C. P. A.; Dantas, T. N. C.; Barros Neto, E. L.; Dantas Neto, A. A. A Review on Chemical Flooding Methods Applied in Enhanced Oil Recovery. Brazilian Journal of Petroleum and Gas, v. 2, n. 2, p. 83-95, 2008.

Jacobs, I.C. Encapsulated breaker for crosslinked acid gel, fracture acidizing fluid containining same method of use thereof, 4.770.796, USA, 1988.

Jacobsen, S.; Fritz, H. G.; Degée, P. H.; Dubois, $\mathrm{PH}$.; Jérome, $\mathrm{R}$. Polylactide (PLA) - A new way of production. Polymer Engineering \& Science, v. 39, p. 1311-1319, 1999.

http://dx.doi.org/10.1002/pen.11518

Kalogeras, I. M.; Lobland, H. E. H. The nature of the glassy state: Structure and transitions. Journal of Materials Education, v34, p.69-94, 2012.
Kopinke, F. D.; Remmler, M.; Mackenzie, K.; Moder, M.; Wachsen, O. Thermal decomposition of biodegradable polyesters.2. Poly(lactic acid). Polymer Degradation and Stability, v. 53, p. 329342, 1996.

http://dx.doi.org/10.1016/0141-3910(96)00102-4

Kumar, R.; Yakubu, M. K.; Anandjiwala, R. D. Biodegradation of flax fiber reinforced poly lactic acid. eXPRESS Polymer Letters, v. 4, p. 423-430, 2010.

Kumari, A.; Yadav, S. K.; Yadav, S. C. Biodegradable polymeric nanoparticles based drug delivery systems. Colloids and Surfaces B: Biointerfaces, v. 75, p. 1-18, 2010. http://dx.doi.org/10.1016/i.colsurfb.2009.09.001

Li, S. Hydrolytic Degradation Characteristics of Aliphatic Polyesters Derived from Lactic and Glycolic Acids. Journal of Biomedical Materials Research, v. 48, p. 342-353, 1999. http://dx.doi.org/10.1002/(SICl)10974636(1999)48:3<342::AID-JBM20>3.0.CO;2-7

Lima, A. F.; Mansur, C. R. E.; Lucas, E. F.; González, G. Polycardanol or sulfonated polystyrene as flocculants for asphaltene dispersions. Energy \& Fuels, v. 24, 2369-2375, 2010. http://dx.doi.org/10.1021/ef901031h

Lucas, E. F.; Soares, B.G.; Monteiro, E. Caracterização de Polímeros: Determinação de Peso Molecular e Análise Térmica. Rio de Janeiro: E-papers, 2001.

Lucas, E. F.; Mansur, C. R. E.; Spinelli, L.; Queirós, Y. G. C. Polymer science applied to petroleum production. Pure and Applied Chemistry, v.81, p.473-494, 2009.http://dx.doi.org/10.1351/PAC-CON-08-07-21

Machado, A. L. C.; Lucas, E. F. Influence of ethylene-co-vinyl acetate copolymers on the flow properties of wax synthetic systems. Journal of Applied Polymer Science, v. 85, p. 1337-1348, 2002. http://dx.doi.org/10.1002/app.10761

Maharana, T.; Mohanty, B.; Negi, Y. S. Meltsolid polycondensation of lactic acid and its biodegradability. Progress in Polymer Science, v. 34, p. 99-114, 2009.

http://dx.doi.org/10.1016/j.progpolymsci.2008.10.001 
Makino, K.; Arakawa, M.; Kondo, T. Preparation and in vitro degradation properties of polylactide microcapsules. Chemical \& Pharmaceutical Bulletin, v. 33, p. 1195-1201, 1985. http://dx.doi.org/10.1248/cpb.33.1195

Melo, M. A.; Lucas, E. F. Characterization and selection of polymer for use in future research on improved oil recovery. Chemistry \& Chemical Technology, v.2, p.295-303, 2008.

Moreira, L. F. B.; González, G; Lucas, E. F. Stabilization of asphaltenes by phenolic compounds extracted from cashew-nut shell liquid. Journal of Applied Polymer Science, v. 73(1), 2934, 1999. http://dx.doi.org/10.1002/(SICI)10974628(19990705)73:1<29::AID-APP3>3.0.CO;2-O

Motta, A. C.; Duek, E. A. R. Síntese, Caracterização e Degradação "in vitro" do Poli(Lácido láctico). Polímeros: Ciência e Tecnologia, v. 16 , p. 26-32, 2006. http://dx.doi.org/10.1590/S010414282006000100008

Muniz, C. A. S.; Castro Dantas, T. N.; Dantas Neto, A. A.; Moura, M. C. P. A.; Dantas, A. C. Cutting Fluid Oily Wastewater: Breakdown and Reuse of The Recovered Oil Phase. Brazilian Journal of Petroleum and Gas, v. 6, n. 2, p. 19-30, 2012. http://dx.doi.org/10.5419/bjpg2012-0002

Nalbandi, A. Kinetics of thermal degradation of polylactic acid under N2 atmosphere. Iranian Polymer Journal, v. 10, p. 371-376, 2001.

Ndazi, B. S.; Karlsson, S. Characterization of hydrolytic degradation of polylactic acid/rice hulls composites in water at different temperatures. eXPRESS Polymer Letters, v. 5, p. 119-131, 2011.

Nostrum, C. F. V.; Veldhuis, T. F.J.; Bos, G. W.; Hennink, W. E. Hydrolytic degradation of oligo(lactic acid): a kinetic and mechanistic study. Polymer, v. 45, p. 6779-6787, 2004.

http://dx.doi.org/10.1016/i.polymer.2004.08.001

Oliveira, G. E.; Mansur, C. R. E.; González, G.;Souza, W. F.; Lucas, E. F. The effect of asphaltenes, naphthenic acids and polymeric inhibitors on the pour point of paraffins solution. Journal of Dispersion Science and Technology, v.28, p.1-8, 2007.

http://dx.doi.org/10.1080/01932690601107526
Orozco, V. H.; Brostow, W.; Chonkaew, W.; Lopez, B. L. Preparation and characterization of poly(lactic acid)-g-maleic anhydride + starch blends. Macromolecular Symposia, v.277, 69-80, 2009. http://dx.doi.org/10.1002/masy.200950309

Park, T. G. Degradation of poly(D,L-lactic acid) microspheres: effect of molecular weight. Journal of Controlled Release, v.30, p.161-173, 1994. http://dx.doi.org/10.1016/0168-3659(94)90263-1

Pezzin, A. P.T.; Zavaglia, C. A. C.; Duek, E. A. R. Estudo da Degradação In Vitro de Blendas de Poli(p-dioxanona)/Poli(I-Ácido Láctico) (PPD/PLLA) Preparadas por Evaporação de Solvente. Polímeros: Ciência e Tecnologia, v. 12, p. 285-294, 2002. http://dx.doi.org/10.1590/s0104-14282002000400012

Ramalho, J. B. V. S.; Ramos, N. A.; Lucas, E. F. The influence of some interfacial properties of PEO-b-PPO copolymers on the dewatering of water-in-oil asphaltene model emulsions. Chemistry \& Chemical Technology, v.3, p.53-58, 2009.

Saha, S. K.;Tsuji, H. Hydrolytic Degradation of Amorphous Films of L-Lactide Copolymers with Glycolide and D-Lactide. Macromolecular Materials and Engineering, v. 291, p. 357-368, 2006. http://dx.doi.org/10.1002/mame.200500386

Schhnabel, W. Polymer degradation - Principles and practical applications. New York: Macmillian Publishing Co., 1981.

Severino, P.; Santana, M. H. A.; Malmonge, S. M.; Souto, E. B. Polímeros Usados como Sistemas de Transporte de Princípios Ativos. Polímeros: Ciência e Tecnologia, v. 21, p. 361-368, 2011. http://dx.doi.org/10.1590/S0104-14282011005000061

Silverstein, R. M.; Bassler, G. C.; Morril, T.C. Identificação espectrométrica de compostos orgânicos, Rio de Janeiro: LTC, 2007.

Spinelli, L.S.; Louvisse, A.M.T.; Lucas, E. F. Residue development caused by the simultaneous use of chemical additives in the oil industry. Petroleum Science and Technology, v. 24, p. 61-68, 2006. http://dx.doi.org/10.1081/LFT$\underline{200044411}$ 
Tokiwa, Y.; Jarerat, A. Biodegradation of poly(Ilactide). Biotechnology Letters, v. 26, p. 771-777, 2004.

http://dx.doi.org/10.1023/B:BILE.0000025927.31028.e3

Tracy, M. A.; Ward, K. L.; Firouzabadian, L.Y.; Wang, N.; Dong, R.; Qian, Y.; Zhang, Y. Factors affecting the degradation rate of poly(lactide-coglycolide) microspheres in vivo and in vitro. Biomaterials, v. 20, p. 1057-1062, 1999. http://dx.doi.org/10.1016/S0142-9612(99)00002-2

Vert, M.; Schwach, G.; Coudane, J. Present and Future of PLA Polymers. Journal of Macromolecular Science, Part A: Pure and Applied Chemistry, v. 32, p. 787-796, 1995. http://dx.doi.org/10.1080/10601329508010289

Vieira, L. C.; Buchuid, M. B.; Lucas, E .F. The influence of pressure and dissolved gases in petroleum on the efficiency of wax deposition inhibitors. Chemistry \& Chemical Technology, v.2, p.211-215, 2008.

Yuan, X.; Mak, A. F. T.; Yao, K. In Vitro Degradation of Poly(L-lactic acid) Fibers in Phosphate Buffered Saline. Journal of Applied Polymer Science, v. 85, p. 936-943, 2002. http://dx.doi.org/10.1002/app.10490
Zhao, J.; Wilkins, R. M. Low Molecular Weight Polylactic Acid as a Matrix for the Delayed Release of Pesticides. Journal of Agricultural and Food Chemistry, v. 53, p. 4076-4082, 2005. http://dx.doi.org/10.1021/if0480400

Zhou, Z. H.; Liu, X. P.; Liu, Q. Q.; Liu, L. H. Morphology, Molecular Mass Changes, and Degradation Mechanism of Poly-L-Lactide in Phosphate-Buffered Solution, China PolymerPlastics Technology and Engineering, v. 47, p. 115120, 2009.

http://dx.doi.org/10.1080/03602550802497206

Zou, H.; Yi, C.; Wang, L.; Liu, H.; Xu, W. Thermal degradation of poly(lactic acid) measured by thermogravimetry coupled to Fourier transform infrared spectroscopy. Journal of Thermal Analysis and Calorimetry, v. 97, p. 929-935, 2009. http://dx.doi.org/10.1007/s10973-009-0121-5 